\title{
CORRIGENDUM
}

\section{Engineered E. coli delivers therapeutic genes to the colonic mucosa}

I Castagliuolo, E Beggiao, P Brun, L Barzon, S Goussard, R Manganelli, C Grillot-Courvalin and G Palù

Gene Therapy (2005) 12, 1158. doi:10.1038/sj.gt.3302574

Correction to: Gene Therapy (2005) 12, 1070-1078. doi:10.1038/sj.gt.3302493

Since publication of the above article the authors have identified an error in Figure 5, the correct figure is shown below. The authors would like to apologize for this mistake.

a
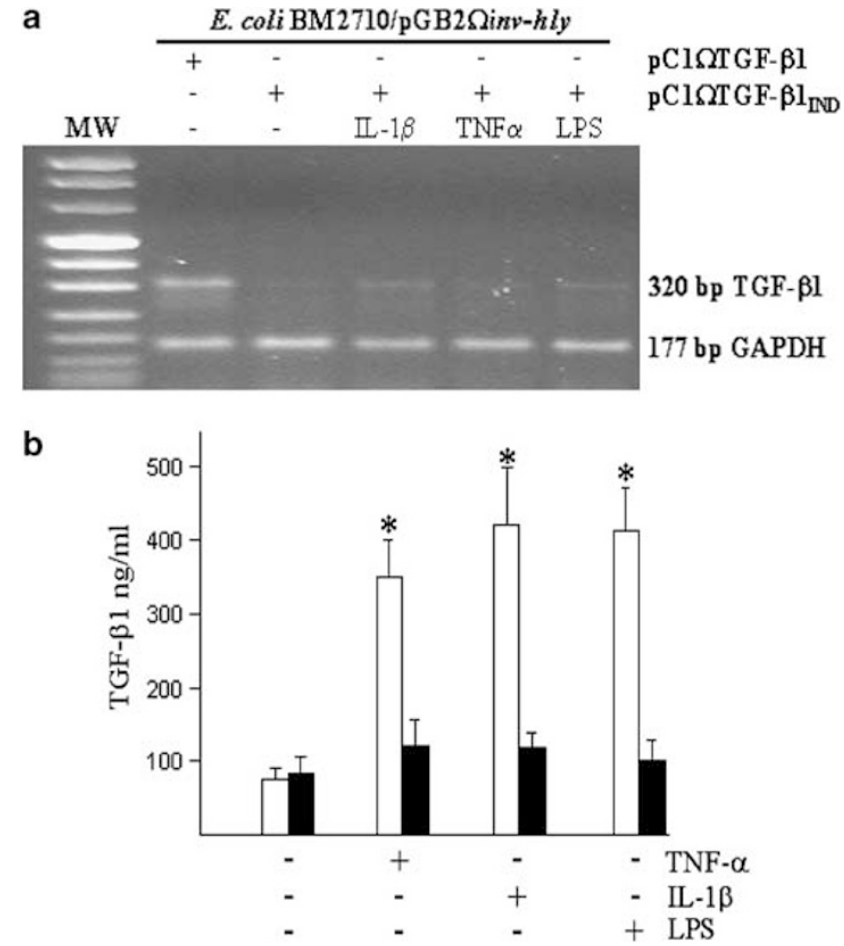

Figure 5 Effect of an inflammation-inducible promoter on plasmid-specific gene expression. CMT-93 cells were incubated for $2 \mathrm{~h}$ with E. coli BM2710/ $p G B 2 \Omega i n v-h l y$ carrying either plasmid $p C 1 \Omega T G F-\beta 1$ or $p C 1 \Omega T G F-\beta 1_{I N D}$. Monolayers were then washed and cultured in complete medium for 48 additional hours. Where specified, $r I L-1 \beta(10 \mathrm{ng} / \mathrm{ml}), r T N F \alpha(10 \mathrm{ng} / \mathrm{ml})$, or LPS $(10 \mu \mathrm{g} / \mathrm{ml})$, was added to the culture medium. (a) RT-PCR was performed on total RNA extracted from monolayers to identify GAPDH and plasmid-specific TGF- $\beta 1$ transcripts. For each condition four separate determinations were performed, a representative experiment is reported. (b) After $24 \mathrm{~h}$, conditioned medium was collected and TGF- $\beta 1$ level was measured by ELISA. Data represent means \pm s.e. of three separate experiments with triplicate determinations. ${ }^{*}$ denotes $P<0.01$ versus control, ${ }^{+}$denotes $P<0.05$ versus control. 